\title{
MONITORING THE IMPACT OF PLANNED OPERATION OF THE "OKTYABRSKA" MINE ON THE POPULATIONS OF ICHTHYOFAUNA AND OTHER COMPONENTS OF THE SAKSAGAN RIVER BIOCENOSIS IN 2020 (KRIVYI RIH, UKRAINE)
}

\section{Marenkov O. M., Aleksieieva A. A.}

\section{INTRODUCTION}

Water ecosystems of small rivers are often exposed to anthropogenic effect associated with mining activities, since mining processes involve the use of water resources. Currently the environmental monitoring over the quality of the water environment influenced by mining, has become a particularly significant issue.

The Saksagan River is an example of a water body located in the center of the industrial agglomeration of Krivyi Rih. The natural regime of the Saksagan River has been changed by the regulating influence of dams, the discharge of mine and waste water, water intake in technical needs for industrial water supply, irrigation, fisheries needs and the regulation of the riverbed for industrial needs.

The "Octyabrska" mine. The planned operation of PJSC "KRYVBASZALIZRUDKOM" lies in continuing the production of highgrade iron ore at the field of the "Octyabrska" mine according to a Special permit for the use of subsoil dated 12.10.2001, № 2557, Order of the State service of Geology and Subsoil of Ukraine dated 31.10.2018, № 410 extension of validity; dated 31.10.2018, № 412 - amendments.

The impact of planned operation on the water environment of the Saksagan River is primarily conditional upon the formed surface run-off of the water from the industrial site of "Octyabrska" mine of PJSC "Kryvbaszalizrudkom", which after purification on a local effluent treatment plant is discharged to the Saksagan River.

The "Octyabrska" mine of PJSC "Krivbasszhelezrudkom" has one release (№ 2) of return water (rain and meltwater from the territory of the industrial site) into the Saksagan River. The discharge of treated wastewater (rain and meltwater from the industrial site) into the Saksagan river is carried out on the basis of a special water use permit № 363/DP/49d-18 dated 27.06.2018.

\section{Materials and methods of the research}

The work on monitoring the impact of the planned operation of the "Octyabrska" mine on the populations of ichthyofauna and other components 
of the Saksagan river biocenosis was carried out by employees of the Hydrobiology, Ichthyology, and Radiobiology research laboratory of the Research Institute of Biology of Oles Honchar DNU in 2019-2020, taking into account the current state of the environmental components, direct and indirect cumulative impact of existing objects.

Hydrochemical research. The research on the hydrochemical regime has been carried out according to generally accepted methods ${ }^{1}$. Hydrobiological samples were collected in June 2020 at 6 sections (stations) of the Saksagan River, namely:

- 500 meters above the discharge of wastewaters (rain and meltwater) of the "Octyabrska" mine (point № 1);

- in the № 1, 2 places of discharge of wastewater (rain and meltwater) of the "Octyabrska" mine (point № 2);

- 500 meters below the discharge of wastewater (rain and meltwater) from the “Octyabrska' mine (point № 3).

Hydrobiological research methods. Phyto-, zooplankton, and zoobenthos samples were collected and processed using traditional hydrobiological methods $^{2}$.

Phytoplankton. Algological water samples were collected using Molchanov bathometer and Apstein grid. The species were identified according to conventional methods ${ }^{3}$. The biomass was calculated through the volume of cells, taking the specific weight of algae equal to one $e^{4}$. The dominance was estimated through biomass. The species is regarded as dominant if its total biomass is at least $80 \%$ of the total phytoplankton biomass.

Zooplankton. Zooplankton was sampled using a common method of straining 50 or $100 \mathrm{dm}^{3}$ of water through the Apstein plankton grid (gauze № 71), followed by fixing with $4 \%$ formaldehyde. The qualitative composition and quantitative development of zooplankton was determined. Quantitative processing of samples was performed by counting in the Bogorov chamber, taking into account the number of organisms of different sizes and age groups. The biomass was calculated using the formula of mass dependence on body length:

$$
\mathrm{w}=\mathrm{ql}^{3} \text {, }
$$

where $l$ is the body length, $w$ is the mass, and $q$ is the proportionality factor.

Zoobenthos. The zoobenthos was sampled with Ekman-Birge bottom sampler (with a capture area of $0.004 \mathrm{~m}^{2}$ ) and hydrobiological scrapers nets

\footnotetext{
${ }^{1}$ Методи гідроекологічних досліджень поверхневих вод / під ред. В.Д. Романенко. Київ, 2006. 628 с.

2 Методические рекомендации по сбору и обработке материалов при гидробиологических исследованиях. Зоопланктон и его продукция. Ленинград : ЗИН, 1984. 35 с.

3 Гринь В.Г. Об’ємно-вагова характеристика провідних видів фітопланктону Нижнього Дніпра. Питання екології і иеенології водних організмів Дніпра. АН УССР. Київ, 1963. С. 35-40.

${ }^{4}$ Щербак В.І. Методи досліджень фітопланктону. Методичні основи гідробіологічних досліджень водних екосистем. Київ, 2002. С. 41-48.
} 
(diameter of the scraper net hoop is $20-25 \mathrm{~cm}$ ), which are more convenient to take samples in shallow water areas of the reservoir at a depth of $1.0-1.5 \mathrm{~m}$. At each station, two samples were selected using a stem bottom sampler and one sample using a hydrobiological scraper net according to the standard method $^{5}$.

The bottom inhabitants were fixed in $4 \%$ formalin solution. The soil was washed through a grid of close-meshed mill gauze. Samples were weighted on torsion scales by groups. The species composition was determined using "MICROmed" XS-2610 and "Carl Zeiss Jenamed 2" microscopes. The average abundance and biomass values for macrozoobenthos groups were calculated as the arithmetic mean where the specified species occurred during the study period. The occurrence is determined for each species (in percent), which is expressed as the ratio of samples where the species was detected to the total number of samples collected during the entire research period at a particular station. This indicator is calculated using the formula:

$$
\mathrm{P}=(\mathrm{m} / \mathrm{n}) 100 \%,
$$

where $m$ is the number of samples (stations) where this species was found, and $\mathrm{n}$ is the total number of samples (stations).

Ichthyofauna. Fish were caught in June in shallow waters. The fishing gear was a $10 \mathrm{~m}$ long cloth drag seine, fish traps, and $1 \mathrm{x} 1 \mathrm{~m}$ lift net. The total catch of juvenile fish was sorted by species, their number was calculated; their length was measured with an accuracy of $1 \mathrm{~mm}$ and the mass of individuals with an accuracy of $0.01 \mathrm{~g}^{6}$. The relative number is calculated as the number of individuals per $100 \mathrm{~m}^{2}$ of the area of the $\mathrm{catch}^{7,8}$. The species were determined according to A.F. Koblytska ${ }^{9}$.

Methods of biotesting. Biotesting of water samples was carried out using experimental test objects Daphnia magna according to KND 211.1.4.054-97. Daphnia juveniles of age less than 24 hours were used to test the toxicity of the samples.

On the day of testing, adult females were separated from the juveniles. The juveniles were selected using a pipette with a wide spout. During the transfer, the juveniles did not contact with the air; the maximum volume during the

\footnotetext{
5 Жадин В.И. Методика изучения донной фауны водоемов и экология донных беспозвоночных). Жизнь пресных вод СССР. Москва : Наука, 1956. Т. 4. Ч. 1. С. 279-382.

${ }^{6}$ Озінковська С.П., Єрко В.М., Коханова Г.Д., Тарасова О.М., Полторацька В.І. Методика збору і обробки іхтіологічних і гідробіологічних матеріалів 3 метою визначення лімітів промислового вилучення риб з великих водосховищ і лиманів України. Київ : ІРГ УААН, 1998. 47 с.

${ }^{7}$ Исследования размножения и развития рыб : методическое пособие / под ред. Б.В. Кошелева, М.В. Гулидова. Москва : Наука, 1981. 224 с.

${ }^{8}$ Кузнецов В.А. Количественный учет молоди рыб в водохранилищах и озерах (методические подходы и возможности). Типовые методики исследования продуктивности видов рыб в пределах их ареалов. Вильнюс, 1985. С. 26-35.

${ }^{9}$ Коблицкая А.Ф. Определитель молоди пресноводных рыб. Москва : Легк. и пищ. пром-сть, 1981. $208 \mathrm{c}$.
} 
selection of juveniles was $2 \mathrm{ml}$. The method is based on determining a difference between the number of dead daphnias in the control and the test samples.

The studied water samples were poured into a $100 \mathrm{~cm}^{3}$ glass container. The same volume of distilled water was added to the control sample (control). 10 daphnias at the age of up to 24 hours were placed in each of the experimental and control vessels. During biotesting daphnias were not fed; the number of living test objects was visually determined at the end of the experiment.

The results were recorded after 96 hours. Daphnias were considered to be alive if they moved freely in the water column and reacted to light. The rest of the daphnias were considered dead. The number of alive daphnias in the control and experiment groups gave arithmetic averages, which were used to calculate the number of dead daphnias in the experiment in relation to the control using the formula (3):

$$
\mathrm{A}=[(\mathrm{Xk}-\mathrm{Xd}) / \mathrm{Xk}] \cdot 100 \%,
$$

where $\mathrm{A}$ is the number of dead daphnias in the experiment relative to the control,\%; Xk is the arithmetic mean of the number of alive daphnias in the control, individuals; $\mathrm{Xd}$ is the arithmetic mean of the number of alive daphnias in the experiment, individuals.

If more than $50 \%$ of the test organisms die within 96 hours, it is considered that the test sample has an acute toxic effect on daphnias; if this amount is less than $50 \%$, it indicates the absence of an acute toxic effect of the experimental sample on the test organisms. The lower the average value of the lethal time, the more toxic the test water is. The results of biotesting are considered reliable if the death of daphnias in the control does not exceed $10 \%$.

Determination of chlorophyll. Plant samples of the coontail (Ceratophyllum demersum L.) were collected in June 2020 at 6 sections of the Saksagan River near the "Octyabrska" mines. The research sites were located 500 meters above the discharge of return water (rain and meltwater) in the areas of discharge of return water (rain and meltwater) and 500 meters below the discharge of return water (rain and meltwater). The content of chlorophylls (Chl $a$, Chl $b$ and total chlorophyll) was determined using the method of J. Wintermans J. F. G. M.De Mots A. $(1965)^{10}$ in ethanol extracts of tree leaves using the KFK-3 spectrophotometer. The concentration of chlorophylls was calculated by equations $(4-6)^{11}$ :

$$
\begin{aligned}
& \mathrm{C}_{\mathrm{Chl} \mathrm{a}}(\mathrm{mg} / \mathrm{l})=13.70 \mathrm{D}_{665}-5.76 \mathrm{D}_{649} \\
& \mathrm{C}_{\mathrm{Chl} \mathrm{b}}(\mathrm{mg} / \mathrm{l})=25.80 \mathrm{D}_{649}-7.60 \mathrm{D}_{665}
\end{aligned}
$$

\footnotetext{
${ }^{10}$ Wintermans J.F.G.M., De Mots A. Spectrophotometric Characteristics of Chlorophyll a and b and Their Phaeophytins in Etanol. Biochimicaet Biophysica Acta. 1965. № 109 (2). P. 448-453.

${ }^{11}$ Current Protocols in Food Analytical Chemistry / E. Wrolstad (Editor-in-Chief; Oregon State University), Terry E. Acree (Cornell University), Eric A. Decker (University of Massachusetts) and other. 2001. $1000 \mathrm{p}$.
} 


$$
\mathrm{C}_{\mathrm{Chl} \mathrm{a+b}}(\mathrm{mg} / \mathrm{l})=6.10 \mathrm{D}_{665}+20.04 \mathrm{D}_{649},
$$

where: $\mathrm{C}_{\mathrm{Chl}}$ a - concentration of chlorophyll a; $\mathrm{C}_{\mathrm{Chl} \mathrm{b}}$ - concentration of chlorophyll b; $\mathrm{D}_{665}-$ optical density of the extract at $\lambda 665 \mathrm{~nm} ; \mathrm{D}_{649}-$ optical density of the extract at $\lambda 649 \mathrm{~nm}$.

The obtained results were subject to the variation statistics processing. The difference significance between the experimental data obtained and the control data was evaluated using the Student's t-test. The null hypothesis was rejected at $\mathrm{p} \leq 0.05$. All calculations were performed using the Statistica 6.0 software package.

\section{General physical and geographical characteristics}

Saksagan is a river in Ukraine, located in the South-Eastern part of the Dnipro Upland, within the Verkhnodniprovsk, Piatykhatky, Sofiyivka and Kryvyi Rih districts of the Dnipropetrovsk region. It is a left tributary of the Inhulets (Dnipro basin). It originates at the point of groundwater orifice to the west of the Adalimivka village, Krynychky district, Dnipropetrovsk region at an altitude of $150 \mathrm{~m}$ above sea level.

The area of the Saksagan River basin has decreased from $2025 \mathrm{~km}^{2}$ to $1970 \mathrm{~km}^{2}$ and thus it passed into the category of "small rivers" from the category of "medium rivers". By current measurements, taking into account all changes in its course within the city of Kryvyi Rih, the length of the river is $140 \mathrm{~km}$. The average width of the stream course is $29-40 \mathrm{~m}$. The river network of the Saksagan basin is moderately developed and consists of 10 rivers more than $10 \mathrm{~km}$ long each, 29 rivers less than $10 \mathrm{~km}$ that have a relatively constant flow, and about 100 insignificant, usually dry draws that have a surface drain during spring snowmelt and summer showers. The main tributaries are the Lozovatka and the Demuryna Rivers. There are no natural lakes in the basin; artificial reservoirs and ponds have a water surface area of $24 \mathrm{~km}^{2}$, including Kresivske $\left(5 \mathrm{~km}^{2}\right)$ and Makortivske $\left(12 \mathrm{~km}^{2}\right)$ reservoirs.

The river valley is straight. Beside the fall of the Demurina River it is mostly indistinctly $\mathrm{V}$-shaped, below it is trapezoidal, and it is $\mathrm{V}$-shaped only in places where the river cuts through a strongly dislocated complex of the Kryvyi Rih metamorphic series. The width of the valley varies from $0.6 \mathrm{~km}$ at the source to $4.5 \mathrm{~km}$ below the Serhiyivka village, most often reaching $1.5-2.5 \mathrm{~km}$. The slopes are mostly outbowed, 30-40 m high, moderately steep. Behind Varvarivka village and below the Bozhedarivka village slopes are weakly desiccated, becoming strongly desiccated farther. They are composed of clay and dusty-heavy loam soils with a lot of crystalline rocks outcrops; limestone is found only in Sayivka village.

The slopes are mostly open, in places of crystalline rocks outcrops it is exposed; slightly and moderately steep slopes are plowed, while steep ones are covered with grass. In the middle and lower reaches the slopes, mainly at 
the left bank, have terraces. The first terrace above flood-plain with a ledge height of $4-6 \mathrm{~m}$ is flooded in many localities due to the construction of Makortivsky reservoir.

The riverbed of the Saksagan is unbranched; up to the village of Varvarivka it is slightly tortuous and below this village it is tortuous. In areas where the river bends around the crystalline rocks, a large number of bends were formed, the largest of which are Kresivsky, Oktyabrsky, Shmakivsky and Mudrenyi.

The riverbed in many places of the upper and middle reaches is weakly embedded in the bottom of the valley. For a considerable length it is dry, the stretches are punctuated with shallow areas and it is overgrown with aquatic vegetation. The prevailing width of the river on the stretches is $20-40 \mathrm{~m}$, the depth is $2-3 \mathrm{~m}$; on the ripples, the riverbed narrows to $5-10 \mathrm{~m}$, and the depth decreases to $0.5-1 \mathrm{~m}$. The river has the greatest width of $600 \mathrm{~m}$ in the upper reaches of the Kresovsky reservoir near the village of Sokolivka.

The river slope is $0.8 \mathrm{~m} / \mathrm{km}$. The flow speed is insignificant, the maximum is $0.4 \mathrm{~m} / \mathrm{s}$ in the lower reaches of the river.

According to the data of 2017-2018 years, the main pollutants coming from permanent water discharges in the Saksagan River are the following: chlorides $624 \mathrm{mg} / \mathrm{dm}^{3}$, sulfates $-1015 \mathrm{mg} / \mathrm{dm}^{3}$, ammonium nitrogen $-0.56 \mathrm{mg} / \mathrm{dm}^{3}$, nitrates $-1.4 \mathrm{mg} / \mathrm{dm}^{3}$, nitrites $-0.07 \mathrm{mg} / \mathrm{dm}^{3}$, petroleum products $-0.3 \mathrm{mg} / \mathrm{dm}^{3}$, iron $-14 \mathrm{mg} / \mathrm{dm}^{3}$, phenols $-0.001 \mathrm{mg} / \mathrm{dm}^{3}$, phosphates $-0.15 \mathrm{mg} / \mathrm{dm}^{3}$, suspended solids $-14 \mathrm{mg} / \mathrm{dm}^{3}$. Total salinity of the Saksagan River water is $2850 \mathrm{mg} / \mathrm{dm}^{3}$.

The natural regime of the river is greatly changed by the regulating influence of dams, the discharge of mine and industrial waters, and the intake of water for technical needs. The largest expenditure of the Saksagan River water reaches $240 \mathrm{~m}^{3} / \mathrm{s}$.

On a Chornohorka site of the "Saksagan" mine the river is directed in an underground reservoir (Saksagan diversion tunnel). The modern creek of the river is located $1.5 \mathrm{~km}$ downstream from the natural on along the flow of Ingulets. It is connected by the Dnipro-Krivyi Rih canal with the Dnipro River.

\section{The results of the research}

Hydrochemical analysis. During the studies on water using the TESTLAB hydrochemical kit (JBL, Germany), the following indicators have been determined: the content of ammonium $\left(\mathrm{NH}_{4}{ }^{+}\right)$, nitrites $\left(\mathrm{NO}_{2}{ }^{-}\right)$, nitrates $\left(\mathrm{NO}_{3}{ }^{-}\right)$, iron $\left(\mathrm{Fe}^{2+}\right)$, phosphates $\left(\mathrm{PO}_{4}{ }^{3-}\right)$. The results of the rapid assessment are shown in the table 1.

According to the study results, the water at all the studied sampling points correspond to the physical and chemical parameters of DSTU 4808: 2007. 
Table 1

Results of rapid assessment of the quality of the water environment of the Saksagan River in the area of issue № 2 of the "Oktyabrska" mine

\begin{tabular}{|c|c|c|c|}
\hline \multirow{2}{*}{ Indicator } & \multicolumn{3}{|c|}{ Date of measurement 09.06.2020 } \\
\cline { 2 - 4 } & Point № 1 & Point № 2 & Point № 3 \\
\hline $\mathrm{NH}_{4}^{+}, \mathrm{mg} / \mathrm{dm}^{3}$ & $<0,05$ & $<0,05$ & $<0,05$ \\
\hline $\mathrm{NO}_{2}^{-}, \mathrm{mg} / \mathrm{dm}^{3}$ & $<0,01$ & $<0,01$ & $<0,01$ \\
\hline $\mathrm{NO}_{3}^{-}, \mathrm{mg} / \mathrm{dm}^{3}$ & $<0,5$ & $<0,5$ & $<0,05$ \\
\hline $\mathrm{Fe}^{2+}, \mathrm{mg} / \mathrm{dm}^{3}$ & $<0,02$ & $<0,02$ & $<0,02$ \\
\hline $\mathrm{PO}_{4}^{3-}, \mathrm{mg} / \mathrm{dm}^{3}$ & $<0,02$ & $<0,02$ & $<0,02$ \\
\hline
\end{tabular}

Note: point № 1: $500 \mathrm{~m}$ above the discharge of return water (rain and meltwater); point № 2: the place of return water discharge (rain and meltwater); point № 3: $500 \mathrm{~m}$ below the discharge of return water (rain and meltwater)

The results of hydrochemical analysis have shown that the content of ammonium nitrogen $\left(\mathrm{NH}_{4}{ }^{+}\right)$at all research points is $0.05 \mathrm{mg} \mathrm{N} / \mathrm{dm}^{3}$, which does not exceed the requirements for water quality and characterizes it within the 1 st quality class. The concentration of ammonium nitrogen in water depends largely on the dryness of the year. The content of nitrites $\left(\mathrm{NO}_{2}^{-}\right)$and nitrates $\left(\mathrm{NO}_{3}{ }^{-}\right)$in all research points also does not exceed the maximum permissible concentrations and corresponds to the 2nd class of water quality. The content of iron $\left(\mathrm{Fe}^{2+}\right)$ in the water at the research points was satisfactory and characterizes it within the 1st quality class.

The phosphate content was kept at the level of $<0.02 \mathrm{mg} / \mathrm{dm}^{3}$, not exceeding the regulatory values.

Comparing the data obtained with previous figures, the content of ammonium nitrogen $\left(\mathrm{NH}_{4}{ }^{+}\right)$at the experimental points has decreased by half. The content of nitrites $\left(\mathrm{NO}_{2}{ }^{-}\right)$in water has also decreased, especially in the place of return water discharge (rain and meltwater). The content of nitrates $\left(\mathrm{NO}_{3}{ }^{-}\right)$, phosphates $\left(\mathrm{PO}_{4}{ }^{3-}\right)$ and iron $\left(\mathrm{Fe}^{2+}\right)$ has not changed significantly comparing to previous studies.

The following parameters have been determined using the EZODO AZ86031 hydrochemical device (Oximeter/pH meter/conductometer/salimeter): temperature $\left(\mathrm{t}^{\circ} \mathrm{C}\right)$, hydrogen index $(\mathrm{pH})$, oxygen content, salinity and conductivity of the water.

The average water temperature at the sampling points is at the level of $+26-27^{\circ} \mathrm{C}$. The hydrogen $\mathrm{pH}$ index fluctuated within the acceptable limits of 8.2-8.6.

The amount of mineralization in various parts of the experimental reservoir slightly varied from $2115.0 \mathrm{mg} / \mathrm{dm}^{3}$ at the point of discharge of return water (rain and meltwater) to $2840.0 \mathrm{mg} / \mathrm{dm}^{3}$ at the point above the discharge of return water (rain and meltwater). The lowest water conductivity index was at 
points below the discharge of return water (rain and meltwater) and reached $431 \mu \mathrm{S}$, and the largest one was noted at a point of the return water discharge (rain and meltwater) and amounted to $445 \mu \mathrm{S}$ (table 2). The water salinity index at the experimental points has not changed much since previous studies. Water conductivity has decreased somewhat, which may be caused by climate changes and temperature conditions.

Table 2

Hydrochemical indicators of the water of the Saksagan River, 09.06.2020

\begin{tabular}{|c|c|c|c|c|c|c|}
\hline Sampling point & $\mathrm{pH}$ & $t^{\circ} \mathrm{C}$ & $\begin{array}{l}\text { Oxygen } \\
\text { content, } \\
\mathrm{mg} / \mathrm{dm}^{3}\end{array}$ & $\begin{array}{c}\text { Oxygen } \\
\text { content, } \\
\%\end{array}$ & $\begin{array}{l}\text { Minerali } \\
\text { zation, } \\
\mathrm{mg} / \mathrm{dm}^{3}\end{array}$ & $\begin{array}{c}\text { Conduc- } \\
\text { tivity, } \\
\mu \mathrm{S}\end{array}$ \\
\hline \multicolumn{7}{|c|}{ "Oktyabrska" mine } \\
\hline $\begin{array}{l}500 \mathrm{~m} \text { above the discharge of return } \\
\text { water (rain and meltwater) }\end{array}$ & 8.6 & 26.8 & 8.1 & 57.9 & 2840.0 & 438.0 \\
\hline $\begin{array}{l}\text { Place of discharge of wastewater } \\
\text { (rain and meltwater) }\end{array}$ & 8.3 & 27.6 & 6.0 & 42.9 & 2115.0 & 445.0 \\
\hline $\begin{array}{l}500 \mathrm{~m} \text { below the discharge of return } \\
\text { water (rain and meltwater) }\end{array}$ & 8.2 & 27.8 & 4.5 & 32.1 & 2456.0 & 431.0 \\
\hline
\end{tabular}

The highest oxygen content in water was recorded in the place above the discharge of return water (rain and meltwater) and reached $57.9 \%$, and the lowest indicator was in the place below the discharge of return water (rain and meltwater), which amounted to $32.1 \%$.

Generally, oxygen deficiency is caused by seasonal fluctuations, and can also be observed in eutrophicated reservoirs containing a large amount of biogenic and humic substances.

Determination of toxicity of the water from Saksagan River in the area of "Oktyabrska" mine discharge on Daphnia magna Straus crustaceans. During the biotesting for the chronic toxic effect of water, it has been revealed that all daphnias were alive in the control samples.

The lowest percentage of dead test objects amounting to $3.3 \%$ was observed in the experimental samples from the discharge points and above the discharge of return water (rain and meltwater). At the point below the discharge of return water (rain and meltwater), the percentage of dead daphnias was $6.7 \%$, which does not exceed the regulatory values (table 3 ).

The analysis of the previous data concerning sampling points near the "Oktyabrska" mine have shown that there is a decrease in the mortality rate of test objects in the water, especially at the sampling point above the discharge of return water (rain and meltwater), where the indicator decreased by almost $10 \%$.

The biotesting has not revealed acute toxic effects of water at experimental sites, but on the contrary, there is a decrease in the water toxicity exposure near the "Oktyabrska" mine. 


\section{Results of biotesting for acute toxic effects of water}

\begin{tabular}{|c|c|c|}
\hline $\begin{array}{l}\text { Name of the sampling point } \\
\text { and repeatability }\end{array}$ & $\begin{array}{l}\text { Number of } \\
\text { daphnias }\end{array}$ & $\begin{array}{l}\text { Number of survivors } \\
\text { Daphne after } 96 \text { hours }\end{array}$ \\
\hline Control 1 & 10 & 10 \\
\hline Control 2 & 10 & 10 \\
\hline Control 3 & 10 & 10 \\
\hline The average percentage of dead daphnias & & $0 \%$ \\
\hline \multicolumn{3}{|c|}{ "Oktyabrska" mine } \\
\hline $\begin{array}{l}1.1 .500 \mathrm{~m} \text { above the discharge of return } \\
\text { water (rain and meltwater) }\end{array}$ & 10 & 10 \\
\hline 1.2 & 10 & 9 \\
\hline 1.3 . & 10 & 10 \\
\hline The average percentage of dead daphnias & \multicolumn{2}{|r|}{$3.3 \%$} \\
\hline $\begin{array}{l}\text { 2.1. Place of discharge of wastewater (rain } \\
\text { and meltwater) }\end{array}$ & 10 & 10 \\
\hline 2.2 . & 10 & 9 \\
\hline 2.3 . & 10 & 10 \\
\hline The average percentage of dead daphnias & \multicolumn{2}{|r|}{$3.3 \%$} \\
\hline $\begin{array}{l}\text { 3.1. } 500 \mathrm{~m} \text { below the discharge of return } \\
\text { water (rain and meltwater) }\end{array}$ & 10 & 9 \\
\hline 3.2 . & 10 & 9 \\
\hline 3.3 . & 10 & 10 \\
\hline The average percentage of dead daphnias & \multicolumn{2}{|r|}{$6.7 \%$} \\
\hline
\end{tabular}

Phytoplankton. The phytoplankton of the Saksagan River in the studied sites of the "Oktyabrska" mine consists of mainly typical species for small and medium-sized rivers of the Steppe zone of Ukraine. Generally, the phytoplankton groups of the river are depleted. Phytoplankton consists of 7 systematic groups of algae, represented by 88 species (Fig. 1).

The green algae species dominate among phytoplankton, which is typical for the summer period. The most common were algae of the genera Clorella and Scenedesmus. Among diatoms, the largest number of species belong to the genera Melosira, Nitzchia, Navicula, Asterionella, and Cyclotella. Among the filamentous blue-green algae, there were algae of the Oscillatoria genus, which are indicators of the beta-mesosaprobic (moderately polluted) zone. The total population and biomass are fairly low.

The highest number of algae was at the point below the return water discharge of the "Oktyabrska" mine (point 3) and amounted to 11.43 million cells $/ \mathrm{dm}^{3}$ with a biomass of $10.84 \mathrm{mg} / \mathrm{dm}^{3}$. The smallest number of algae was in the point of discharge of return water (rain and meltwater) of the "Oktyabrska" mine and reached 6.29 million cells $/ \mathrm{dm}^{3}$ with a biomass of $7.01 \mathrm{mg} / \mathrm{dm}^{3}$ (table 4). This decrease in population can be explained by a long rain period in early summer, which led to the dilution of river water with rainwater. 


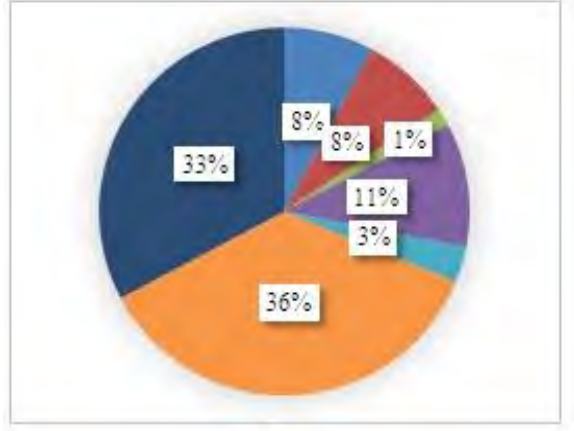

$\mathbf{A}$

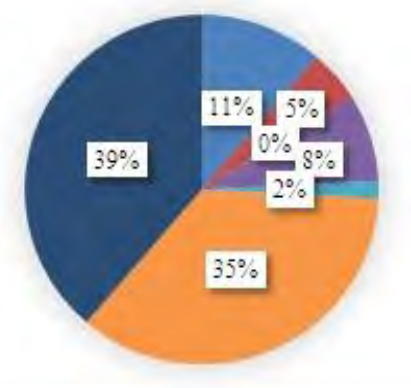

B

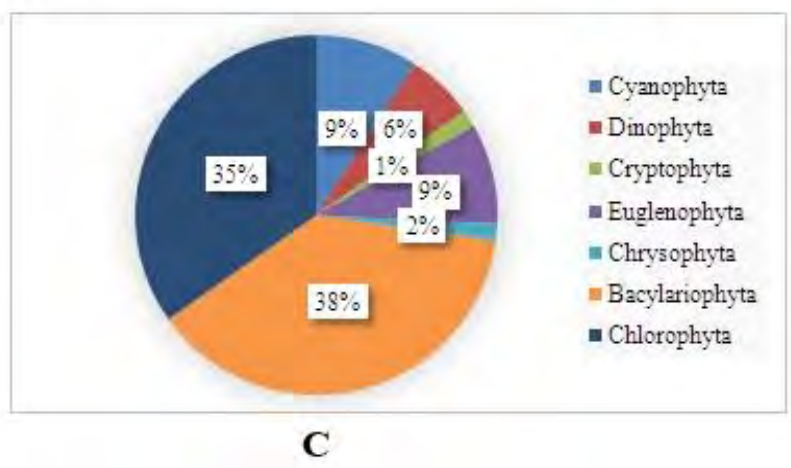

Figure 1. Percentage of algal taxonomic groups $A$ - point № 1: $500 \mathrm{~m}$ above the discharge of return water (rain and meltwater); $B$ - point № 2: the place of return water discharge (rain and meltwater); $C$ - point № 3: $500 \mathrm{~m}$ below the discharge of return water (rain and meltwater)

The algal flora complex found in the studied section of the city of Saksagan River near the "Oktyabrska" mine is not typical for clean rivers with their own natural insignificant pollution and is inherent in anthropogenic loaded and overgrown reservoirs.

Impact of planned Operation of the "Oktyabrska" mine on the phytoplankton of the riverbed of the Saksagan River. Mainly, the lowest algae number is observed at the point of discharge of return water (rain and meltwater)' the highest number and biomass is noted at the point $500 \mathrm{~m}$ below the discharge of return water (rain and meltwater). During the operation of mines, groups of phytoplankton can be partially damaged in rivers, but the recovery of phytoplankton is quite fast, especially in the warm season.

Microphytobenthos. The species composition of microphytobenthos near the "Oktyabrska" mine consists of widespread species of algae, dominated by representatives of two divisions of algae: diatoms (Bacillariophyceae) and blue-green algae (Cyanophyceae). Following species among diatoms have high development indicators: Pinnularia major (Kutz.) Rabenh. and Staurosira construens Ehrenb. These are eurytopic algae, typical inhabitants of bentofauna, usually widespread in shallow waters with a slightly silty sand. Cyclotella sp. and Amphora veneta Kütz. are facultative benthic algae that grow freely in the littoral of the river. 
Table 4

The number and biomass of phytoplankton groups in littoral areas of the Saksagan River near the "Oktyabrska" mine, June 2020

\begin{tabular}{|c|c|c|c|c|}
\hline \multirow{2}{*}{ Taxons } & \multirow{2}{*}{ Indicator } & \multicolumn{3}{|c|}{ "Oktyabrska" mine } \\
\hline & & Point № 1 & Point № 2 & Point № 3 \\
\hline \multirow[t]{2}{*}{ Bacillariophyta } & $\mathrm{N}$ & 1.6 & 2.7 & 2.8 \\
\hline & B & 1.76 & 2.02 & 4.11 \\
\hline \multirow[t]{2}{*}{ Cyanophyta } & $\mathrm{N}$ & 1.2 & 1.8 & 3.7 \\
\hline & B & 0.1 & 0.17 & 0.25 \\
\hline \multirow{2}{*}{ Chlorophyta } & $\mathrm{N}$ & 2.6 & 0.95 & 3.7 \\
\hline & B & 1.88 & 0.25 & 1.68 \\
\hline \multirow[t]{2}{*}{ Euglenophyta } & $\mathrm{N}$ & 0.42 & 0.12 & 0.46 \\
\hline & B & 1.32 & 0.58 & 1.65 \\
\hline \multirow[t]{2}{*}{ Chryptophyta } & $\mathrm{N}$ & 0.04 & 0.04 & 0.04 \\
\hline & B & 0.02 & 0.02 & 0.02 \\
\hline \multirow[t]{2}{*}{ Dinophyta } & $\mathrm{N}$ & 0.46 & 0.5 & 0.42 \\
\hline & B & 3.92 & 3.88 & 3.02 \\
\hline \multirow[t]{2}{*}{ Chrysophyta } & $\mathrm{N}$ & 0.45 & 0.18 & 0.31 \\
\hline & B & 0.31 & 0.09 & 0.11 \\
\hline \multirow[t]{2}{*}{ Total: } & $\mathbf{N}$ & 6.77 & 6.29 & 11.43 \\
\hline & B & 9.31 & 7.01 & 10.84 \\
\hline
\end{tabular}

Note: point № 1: $500 \mathrm{~m}$ above the discharge of return water (rain and meltwater); point № 2: the place of return water discharge (rain and meltwater); point № 3: $500 \mathrm{~m}$ below the discharge of return water (rain and meltwater). $\mathrm{N}$ - number of phytoplankton, million cells $/ \mathrm{dm}^{3} ; \mathrm{B}-$ phytoplankton biomass, $\mathrm{mg} / \mathrm{dm}^{3}$

Among the blue-green algae, the dominant microphytobenthos complex included 4 dominant species: Aphanizomenon flos-aquae (L.) Ralfs, Merismopedia elegans, Oscillatoria ucrainica Vladimir. and Oscillatoria amphibian Ag. Aphanizomenon flos-aquae (L.) Ralfs and Merismopedia elegans are species that settle to the bottom from the water column. Oscillatoria ucrainica Vladimir is a widespread species. They are obligate benthic algae which was found mainly on silted and slightly silted sand. At all 3 research points of the Saksagan River near the "Oktyabrska" mine, the facultative benthic-planktonic alga Oscillatoria amphibian $\mathrm{Ag}$ is found in significant quantities both on the bottom and in the water column of the littoral zone.

During the study period, it has been established that the planned operation of the "Oktyabrska" mine do not harm the microphytobentos groups.

Zooplankton. 49 species of zooplankton are recorded at all the studied points of the Saksagan River near the "Oktyabrska" mine, including 29 rotifers, 11 copepods, 8 cladocerans, and veligers of 1 species of dreissens. 
The number of species at the points studied varied from 31 species (point 2) to 38 species (point 3). The smallest number of species is observed in the place of discharge of return water (rain and meltwater), due to a decrease in the number of the Copepoda representatives (table 5).

Table 5

The number of zooplankton groups in the Saksagan River, June 2020

\begin{tabular}{|c|l|c|c|c|}
\hline \multirow{2}{*}{ № } & \multirow{2}{*}{ Taxons } & \multicolumn{3}{|c|}{ “Oktyabrska” mine } \\
\cline { 3 - 5 } & & Point № 1 & Point № 2 & Point № 3 \\
\hline 1 & Rotatoria & 19 & 17 & 21 \\
\hline 2 & Cladocera & 4 & 7 & 7 \\
\hline 3 & Copepoda & 9 & 6 & 9 \\
\hline 4 & Veliger Dreissena & 1 & 1 & 1 \\
\hline & Total & $\mathbf{3 3}$ & $\mathbf{3 1}$ & $\mathbf{3 8}$ \\
\hline
\end{tabular}

Note: point № 1: $500 \mathrm{~m}$ above the discharge of return water (rain and meltwater); point № 2: the place of return water discharge (rain and meltwater); point № 3: $500 \mathrm{~m}$ below the discharge of return water (rain and meltwater)

The following species dominated in zooplankton during the study period: Cyclops strenuous, Cyclops strenuous, Ascomorpha agilis, Asplanchna sieboldin, Brachionus angularis, Euchlanis dilatata, Synchaeta sp., Bosmina longirostris, Moina macrocopa, Keratella quadrata. These species were found at almost all research points. Among the littoral biotopes, the largest number of species was observed in the open littoral, the smallest one in the cane thickets.

At the point $500 \mathrm{~m}$ above the discharge of return water (rainwater and snowmelt) veligers of dreissens were absent. There is a decrease in the number of filter-feeding organism under the direct influence of the mine operation (point 2). The lowest number and biomass of zooplankton was observed in the place of discharge of return water (rain and meltwater) and amounted to 5.18 thous. ind. $/ \mathrm{m}^{3}$ and $0.07 \mathrm{~g} / \mathrm{m}^{3}$, respectively (table 6).

Impact of planned Operation of the "Oktyabrska" mine on the zooplankton of the riverbed of the Saksagan River. Despite the decrease in the number and biomass of zooplankton at the point of direct impact on the aquatic ecosystem of the Saksagan River, at a distance of $500 \mathrm{~m}$ below and $500 \mathrm{~m}$ above the discharge of return water (rain and meltwater), there is a restoration of zooplankton biological diversity and an increase in its number and biomass.

Thus, the zooplankton of the Saksagan River does not undergo significant changes under the influence of planned operation of the "Oktyabrska" mine (due to waste water) because of its high adaptive and regenerative capacity and is in a fairly satisfactory environmental condition. 
Number and biomass of zooplankton groups in littoral areas of the Saksagan River, June 2020

\begin{tabular}{|c|c|c|c|c|c|}
\hline \multirow{2}{*}{ № } & \multirow{2}{*}{ Taxons } & Indicator & \multicolumn{3}{|c|}{ "Oktyabrska" mine } \\
\hline & & & Point № 1 & Point № 2 & Point № 3 \\
\hline \multirow[t]{2}{*}{1} & Rotatoria & $\mathrm{N}$ & 6.04 & 1.48 & 13.19 \\
\hline & & B & 0.03 & 0.02 & 0.05 \\
\hline \multirow[t]{2}{*}{2} & Cladocera & $\mathrm{N}$ & 0.05 & 0.02 & 0.06 \\
\hline & & B & 0.01 & 0.01 & 0.01 \\
\hline \multirow[t]{2}{*}{3} & Copepoda & $\mathrm{N}$ & 18.14 & 3.67 & 15.18 \\
\hline & & B & 0.18 & 0.03 & 0.12 \\
\hline \multirow[t]{4}{*}{4} & Veliger Dreissena & $\mathrm{N}$ & 0.01 & 0.01 & 0.01 \\
\hline & & B & 0.01 & 0.01 & 0.01 \\
\hline & \multirow{2}{*}{ Total } & $\mathbf{N}$ & 24.24 & 5.18 & 28.44 \\
\hline & & B & 0.23 & 0.07 & 0.19 \\
\hline
\end{tabular}

Note: point № 1: $500 \mathrm{~m}$ above the discharge of return water (rain and meltwater); point № 2: the place of return water discharge (rain and meltwater); point № 3:500 m below the discharge of return water (rain and meltwater). $\mathrm{N}$ - number of zooplankton, thous. ind. $/ \mathrm{m}^{3}$; $\mathrm{B}$ - zooplankton biomass, $\mathrm{g} / \mathrm{m}^{3}$

Zoobenthos. The benthic fauna of the studied areas of the Saksagan River near the "Oktyabrska" mine is characterized by a poor diversity. Its composition consists of 70 species of invertebrates, which belong to 24 taxonomic groups (table 7). The fluctuations in number of species for different sites ranged from 36 species (at the point $500 \mathrm{~m}$ above the discharge of return water (rain and meltwater) of the "Oktyabrska" mine) to 58 species (at the point $500 \mathrm{~m}$ below the discharge of return water (rain and meltwater) of the mine). There is a relative impoverishment of species diversity, which is a result of silting and overgrowth in some parts of the river. There is a noticeable decreasing tendency for their number due to the loss of oxyphilous species, which indicates the deterioration of the river ecosystem.

The most common species were: Lymnaea stagnalis, Physa fontinalis, Viviparus viviparous, Limnodrilus claparedeanus, Limnodrilus hoffmeisteri, Paranais listoralis, Psammoryctides albicola, Tubifex tubifex, Limnomysis behedeni, Pterocuma rostrate, Ecnomus tennelus, Chironomus sp., Cricotopus silvestris, Gliptotendipes gripekoveni, Hydrohaenus lugubris, Polypedilum convictum, Polypedilum convictum.

In the area of operation of the "Oktyabrska" mine, the largest number and biomass of benthos is at a point $500 \mathrm{~m}$ below the discharge of rain and meltwater on a stony site (table 8). It is caused by the shallow water of the 
site, the presence of wood residues and snags, rocks and the presence of macrophyte groups that makes a large number and variety of biotopes.

Table 7

Taxonomic composition of the zoobenthos representatives in the research sites of the Saksagan River, June 2020

\begin{tabular}{|c|c|c|c|c|}
\hline \multirow{2}{*}{ № } & \multirow{2}{*}{ Invertebrate taxa } & \multicolumn{3}{|c|}{ "Oktyabrska" mine } \\
\hline & & Point № 1 & Point № 2 & Point № 3 \\
\hline 1 & Hydrozoa & 1 & 1 & 0 \\
\hline 2 & Bryozoa & 0 & 1 & 1 \\
\hline 3 & Bivalvia & 0 & 2 & 2 \\
\hline 4 & Gastropoda & 3 & 6 & 9 \\
\hline 5 & Nematoda & 1 & 1 & 1 \\
\hline 6 & Oligochaeta & 9 & 10 & 11 \\
\hline 7 & Hirudinea & 0 & 1 & 1 \\
\hline 8 & Gammaridae & 1 & 2 & 2 \\
\hline 9 & Misidacea & 1 & 1 & 1 \\
\hline 10 & Cumacea & 1 & 1 & 1 \\
\hline 11 & Decapoda & 0 & 0 & 1 \\
\hline 12 & Ephemiroptera & 0 & 1 & 2 \\
\hline 13 & Trichoptera & 1 & 2 & 1 \\
\hline 14 & Odonata & 0 & 1 & 1 \\
\hline 15 & Lepidoptera & 0 & 1 & 1 \\
\hline 16 & Heteroptera & 1 & 0 & 1 \\
\hline 17 & Coleoptera & 0 & 2 & 2 \\
\hline 18 & Chironomidae & 17 & 16 & 16 \\
\hline 19 & Ceratopogonidae & 0 & 0 & 1 \\
\hline 20 & Culicida & 0 & 1 & 0 \\
\hline 21 & Ephydridae & 0 & 1 & 0 \\
\hline 22 & Simmulidae & 0 & 0 & 1 \\
\hline 23 & Psychodidae & 0 & 0 & 1 \\
\hline 24 & Sciomyzidae & 0 & 0 & 1 \\
\hline & Total: & 36 & 51 & 58 \\
\hline
\end{tabular}

Note: point № 1: $500 \mathrm{~m}$ above the discharge of return water (rain and meltwater); point № 2: the place of return water discharge (rain and meltwater); point № 3: $500 \mathrm{~m}$ below the discharge of return water (rain and meltwater)

The highest values of saprobity were recorded in areas with silty soil: points 1,3 . The oligochaetes and chironomids dominated here (table 9). 
Table 8

Number and biomass of the zoobenthos development

\begin{tabular}{|l|c|}
\hline \multicolumn{1}{|c|}{ Sampling stations } & June 2020 \\
\hline \multicolumn{1}{|c|}{ "Oktyabrska" mine } \\
\hline $\begin{array}{l}\text { 1.500 m above the discharge of return water } \\
\text { (rain and meltwater) }\end{array}$ & $\underline{3.45}$ \\
\hline 2. Place of discharge of wastewater (rain and meltwater) & $\underline{4.25}$ \\
\hline $\begin{array}{l}\text { 3.500 m below the discharge of return water } \\
\text { (rain and meltwater) }\end{array}$ & $\underline{5.92}$ \\
\hline Average & $\underline{4.69}$ \\
\hline
\end{tabular}

Note: numerator - number, thous.ind. $/ \mathrm{m}^{2}$, denominator -biomass, $\mathrm{g} / \mathrm{m}^{2}$

Table 9

\section{The saprobity index of experimental sites on the Saksagan River, June 2020}

\begin{tabular}{|c|l|c|}
\hline $\begin{array}{c}\text { Station } \\
\text { number }\end{array}$ & \multicolumn{1}{|c|}{ Point characteristics } & $\begin{array}{c}\text { The saprobity } \\
\text { index }\end{array}$ \\
\hline \multicolumn{3}{|c|}{ "Oktyabrska" mine } \\
\hline 1 & $\begin{array}{l}500 \text { m above the discharge of return water } \\
\text { (rain and meltwater), rocky, silty clay }\end{array}$ & 3.16 \\
\hline 2 & $\begin{array}{l}\text { Place of discharge of wastewater } \\
\text { (rain and meltwater), muddy bottom }\end{array}$ & 3.85 \\
\hline 3 & $\begin{array}{l}500 \text { m below the discharge of return water } \\
\text { (rain and meltwater), muddy bottom, low flow }\end{array}$ & 2.76 \\
\hline
\end{tabular}

In the studied section of the river, the highest saprobity index has been recorded in the area influenced by wastewater discharge (rain and meltwater), which is associated with the development of polysaprobic species, such as oligochaetes from the Tubificidae family and Chironomus Chironomidae. On such soils, there is the greatest species diversity among other soils, owing to chironomid larvae. Water scorpions, gammarids, polychaetes, leeches, bryozoans, diving beetles, mollusks acquired significant development and the greatest species diversity in the flowing and stony areas below the discharge of return water (rain and meltwater) (point 3). The average number of invertebrates in the area of operation of the "Oktyabrska" mine was 4.53 thous. ind. $/ \mathrm{m}^{2}$ with a biomass of $5.33 \mathrm{~g} / \mathrm{m}^{2}$.

No rare or endangered species have been found among the benthic groups.

Impact of planned operation of the "Oktyabrska" mine on benthic groups. The study results have shown that upon the indicators of the qualitative and quantitative composition of the zoobenthos of the Saksagan 
River in the area around the "Oktyabrska" mine, the benthic groups do not suffer critical changes under the influence of the planned activities of the mine.

Ichthyofauna. Within the studied stations near the "Oktyabrska" mine, the modern fish species composition consists of 15 species of fish that belong to 6 families (Clupeidae - 1; Cyprinidae - 7; Gasterosteidae - 1; Cobitidae - 1; Centrarchidae - 1; Gobiidae - 4), which is $40.5 \%$ of the total fish species composition of the Saksagan River for the entire period of ichthyological research (since the 30s of the XX century). In the previous research period (in the fall of 2019), 14 fish species were recorded on the river section. The species composition of the river was replenished with species of the gudgeon family: racer goby, round goby, tubenose goby, as well as with functionally dangerous self-colonized group of alien species such as stone moroko and pumpkinseed. In addition, the spawning ground of the threespined stickleback Gasterosteus aculeatus (Linnaeus, 1758) has been found, which is located at a point $500 \mathrm{~m}$ below the return water discharge (rain and meltwater). The short-cycle fish species, such as stone moroko, bitterling and bleach, which have a high range of adaptations to the transformed reservoirs dominate in the area of the Saksagan River near the "Oktyabrska" mine. The number of bitterling reached 168.12 ind. $/ 100 \mathrm{~m}^{2}$ at a point $500 \mathrm{~m}$ below the discharge of return water (rain and meltwaters) of the "Oktyabrska" mine, with an average number and biomass in the area influenced by the mine amounting to 68.47 ind. $/ 100 \mathrm{~m}^{2}$ and $22.20 \mathrm{~g} / 100 \mathrm{~m}^{2}$, respectively (table 10). The number of bitterling fluctuates significantly, which is caused by cyclical phenomena: in 2018, it was 392 ind./100 $\mathrm{m}^{2}$, in the autumn of 2019 it was 49.39 ind. $/ 100 \mathrm{~m}^{2}$. Such fluctuation in fish amounts is also related to the sampling season and water temperature.

Table 10

Species composition, number and biomass of fish in the Saksagan River, "Oktyabrska" mine June 2020

\begin{tabular}{|c|c|c|c|c|c|c|c|c|c|c|}
\hline \multirow[b]{3}{*}{$\begin{array}{l}\text { № } \\
\text { 3/ח }\end{array}$} & \multirow[b]{3}{*}{ Species of fish } & \multirow[b]{3}{*}{ age } & \multicolumn{8}{|c|}{ "Oktyabrska" mine } \\
\hline & & & \multicolumn{2}{|c|}{ Point № 1} & \multicolumn{2}{|c|}{ Point № 2} & \multicolumn{2}{|c|}{ Point № 3} & \multicolumn{2}{|c|}{ Average } \\
\hline & & & 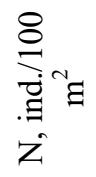 & $\begin{array}{l}\sum_{\infty}^{2} \\
\infty^{n}\end{array}$ & 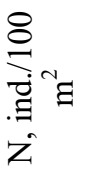 & $\begin{array}{l}\sum_{\infty}^{\infty}{ }^{2} \Xi \\
\infty^{n}\end{array}$ & 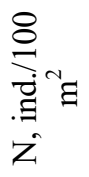 & $\sum_{\substack{\infty \\
\infty}}^{\infty}$ & 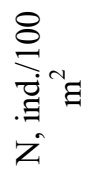 & 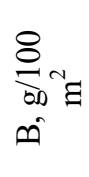 \\
\hline 1 & 2 & 3 & 4 & 5 & 6 & 7 & 8 & 9 & 10 & 11 \\
\hline \multicolumn{11}{|c|}{ Clupeidae Cuvier, 1816} \\
\hline 1 & 2 & 3 & 4 & 5 & 6 & 7 & 8 & 9 & 10 & 11 \\
\hline 1 & $\begin{array}{l}\text { Azov Sea kilka } \\
\text { Clupeonella cultriventris } \\
\text { (Nordmann, 1840) }\end{array}$ & б/в & 0.86 & 0.74 & - & - & - & - & 0.29 & 0.25 \\
\hline \multicolumn{11}{|c|}{ Cyprinidae Fleming, 1822} \\
\hline 2 & $\begin{array}{l}\text { Bleack Alburnus } \\
\text { alburnus } \\
\text { (Linnaeus, 1758) }\end{array}$ & б/в & 13.28 & 44.22 & - & - & 2.45 & 4.48 & 7.87 & 24.35 \\
\hline
\end{tabular}


Table 10 (Continued)

\begin{tabular}{|c|c|c|c|c|c|c|c|c|c|c|}
\hline 1 & 2 & 3 & 4 & 5 & 6 & 7 & 8 & 9 & 10 & 11 \\
\hline \multirow[t]{3}{*}{3} & \multirow{3}{*}{$\begin{array}{l}\text { Prussian carp Carassius } \\
\text { gibelio (Bloch, 1782) }\end{array}$} & $0+$ & 0.66 & 0.22 & 2.28 & 0.78 & 2.65 & 0.28 & 1.86 & 0.43 \\
\hline & & $1+$ & - & - & 0.88 & 2.38 & 1.32 & 1.65 & 1.10 & 2.02 \\
\hline & & $2+$ & - & - & 0.22 & 6.12 & 0.48 & 13.25 & 0.35 & 9.69 \\
\hline 4 & $\begin{array}{l}\text { Sunbleak Leucaspius } \\
\text { delineatus } \\
\text { (Heckel, 1843) }\end{array}$ & б/в & 0.21 & 0.02 & - & - & - & - & 0.21 & 0.02 \\
\hline 5 & $\begin{array}{l}\text { Stone morokko } \\
\text { Pseudorasbora parva } \\
\text { (Temminck et Schlegel, } \\
1846 \text { ) } \\
\end{array}$ & $\mathrm{n} / \mathrm{a}$ & 10.36 & 2.34 & 7.16 & 1.08 & 32.24 & 7.48 & 16.59 & 3.63 \\
\hline 6 & $\begin{array}{l}\text { Bitterling Rhodeus } \\
\text { amarus (Bloch, 1782) }\end{array}$ & $\mathrm{n} / \mathrm{a}$ & 16.16 & 6.23 & 21.12 & 28.15 & 168.12 & 32.21 & 68.47 & 22.20 \\
\hline \multirow[t]{2}{*}{7} & \multirow{2}{*}{$\begin{array}{l}\text { Roach Rutilus rutilus } \\
\text { (Linnaeus, 1758) }\end{array}$} & $0+$ & 2.68 & 0.34 & 2.48 & 0.45 & 3.62 & 0.66 & 2.93 & 0.48 \\
\hline & & $1+$ & 0.14 & 1.12 & 0.22 & 1.48 & 8.25 & 1.24 & 2.87 & 1.28 \\
\hline \multirow[t]{3}{*}{8} & \multirow{3}{*}{$\begin{array}{l}\text { Common rudd } \\
\text { Scardinius } \\
\text { erythrophthalmus } \\
\text { (Linnaeus, 1758) }\end{array}$} & $0+$ & 0.20 & 0.09 & 0.64 & 0.18 & 7.24 & 0.72 & 2.69 & 0.33 \\
\hline & & $1+$ & 0.12 & 0.22 & - & - & 12.04 & 3.45 & 6.08 & 1.84 \\
\hline & & $2+$ & - & - & - & - & 0.86 & 14.22 & 0.86 & 14.22 \\
\hline \multicolumn{11}{|c|}{ Cobitidae Swainson, 1839} \\
\hline 9 & $\begin{array}{l}\text { Weatherfish Cobitis } \\
\text { taenia Linnaeus, } 1758\end{array}$ & $\mathrm{n} / \mathrm{a}$ & 0.44 & 0.46 & 1.64 & 1.89 & 1.44 & 1.24 & 0.88 & 1.20 \\
\hline \multicolumn{11}{|c|}{ Centrarchidae Bleeker, 1759} \\
\hline 10 & $\begin{array}{l}\text { Pumpkinseed Lepomis } \\
\text { gibbosus } \\
\text { (Linnaeus, 1758) }\end{array}$ & $\mathrm{n} / \mathrm{a}$ & - & - & - & - & 4.76 & 20.48 & 1.59 & 6.83 \\
\hline \multicolumn{11}{|c|}{ Gobiidae Fleming, 1822} \\
\hline 11 & $\begin{array}{l}\text { Racer goby Babka } \\
\text { gymnotrachelus } \\
\text { (Kessler, 1857) }\end{array}$ & $\mathrm{n} / \mathrm{a}$ & - & - & 1.44 & 0.43 & 3.23 & 3.67 & 1.56 & 1.37 \\
\hline 12 & $\begin{array}{l}\text { Monkey goby Neogobius } \\
\text { fluviatilis (Pallas, 1814) }\end{array}$ & $\mathrm{n} / \mathrm{a}$ & - & - & 1.32 & 1.46 & 2.42 & 1.14 & 1.25 & 0.87 \\
\hline 13 & \begin{tabular}{|l} 
Round goby Neogobius \\
melanostomus \\
(Pallas, 1814)
\end{tabular} & $\mathrm{n} / \mathrm{a}$ & 2.24 & 1.46 & 3.86 & 1.12 & 2.66 & 1.08 & 2.92 & 1.22 \\
\hline 14 & \begin{tabular}{|l|} 
Tubenose goby \\
Proterorhinus \\
marmoratus \\
(Pallas, 1814) \\
\end{tabular} & $\mathrm{n} / \mathrm{a}$ & 0.36 & 0.07 & 2.93 & 0.56 & 2.03 & 0.96 & 1.77 & 0.53 \\
\hline \multicolumn{11}{|c|}{ Gasterosteidae Bonaparte, 1831} \\
\hline \multirow[t]{2}{*}{15} & $\begin{array}{l}\text { Three-spined stickleback } \\
\text { Gasterosteus aculeatus } \\
\text { (Linnaeus, 1758) }\end{array}$ & $\mathrm{n} / \mathrm{a}$ & - & - & 23.45 & 2.67 & - & - & 23.45 & 1.34 \\
\hline & Total: & & 47.71 & $\mathbf{5 7 . 5 3}$ & 46.19 & 69.64 & 48.75 & 232.36 & 105.54 & 70.61 \\
\hline
\end{tabular}

Note: point № 1: $500 \mathrm{~m}$ above the discharge of return water (rain and meltwater); point № 2: the place of return water discharge (rain and meltwater); point № 3: $500 \mathrm{~m}$ below the discharge of return water (rain and meltwater). $\mathrm{N}-$ number of ind. $/ 100 \mathrm{~m}^{2} \mathrm{~B}$ - biomass $\mathrm{g} / 100 \mathrm{~m}^{2}$; Age $-\mathrm{n} / \mathrm{a}$-without age determination, 0+ - yearling, 1+ - two summers, 2+ three summers, $3+-$ four summers. "-" the species was not found in the catches

The average number of fish in the studied areas of the Saksagan River was 1 ind. $/ 100 \mathrm{~m}^{2}$, and the biomass was $70.61 \mathrm{~g} / 100 \mathrm{~m}^{2}$. This decrease in number and biomass can also be explained by a poor feed base (by benthos) on the 
river section near the "Oktyabrska" mine. The increase in the number and biomass of fish is observed at the point $500 \mathrm{~m}$ below the discharge of returm water (rain and meltwater), which is most likely caused by the restoration of the natural food base and a favorable oxygen regime.

During the research period, fish that have a protected status and are listed In the Red book of the Dnipropetrovsk region and the Red book of Ukraine have not been detected within the area of the planned poeration of the "Oktyabrska" mine.

Vegetation of the banks and shallow waters of the Saksagan River near the "Oktyabrska" mine. The flora of the studied coastal territories and water area is characterized by a small floral diversity due to the significant anthropogenic exposure on the territory (conditions of a large industrial center) through which the Saksagan River flows. By the biological and ecological characteristics, the vegetation of the studied areas is mainly composed of species of the corresponding elements of the landscape, but with a significant admixture of adventive species.

The coastal zone is dominated by species of woody and shrubby plants: boxelder maple (Acer negundo L.), white mulberry (Morus alba L.), Siberian elm (Ulmus pumila L.), black elder (Sambucus nigra L.), common hop (Humulus lupulus L.). The following species are more rare: Siberian apricot (Armeniaca vulgaris Lam.), black locust (Robinia pseudoacacia L.), desert false indigo (Amorpha fruticosa L.), varnish tree (Ailanthus altissima Mill.), common hornbeam (Carpinus betulus L.), common pear (Pyrus communis L.), dog rose (Rosa canina L.), Lombardy poplar (Populus italica (Du Roi) Moench), common buckthorn (Rhamnus cathartica L.).

The grass cover is represented by following species: Volga fescue (Festuca valesiaca Gaud.), false mockorange ( $F$. rupicola Heuft), annual meadowgrass (Poa angustifolia L.), prairie Junegrass (Koeleria cristata (L.) Pers.), smooth brome (Bromopsis inermis (Leyss.) Holub), narrowleaf plantain (Plantago lanceolata L.) and common plantain (P. major L.), nodding plumeless thistle (Carduus nutans L.), common vetch (Vicia sativa L.), crownvetch (Coronilla varia L.), white clover (Trifolium repens L.), yellow alfalfa (Medicago romanica Prod.), spurge (Euphorbia stepposa Zoz.), black fruit wolfberry (Galium ruthenicum L.), woodland sage (Salvia nemorosa L.), Austrian wormwood (Artemisia austriaca Jacq.), meadow saxifrage (Seseli campestre Bess.), catmint (Nepeta parviflora Bieb.), creeping buttercup (Ranunculus repens L.), common yarrow (Achillea millefolium L.). groundsel (Senecio vulgaris L.), common dandelion (Taraxacum officinale L.), diffuse wallflower (Erysimum diffusum Ehrh.).

In the shallow waters of the riverbed of the Saksagan River and on its swampy, silty banks, a complex of associations of aeroaquatic vegetation with the participation of swamp and weed species has formed. The vegetation of 
the watercourse is represented by almost continuous thickets of higher aquatic plants: common reed (Phragmtes australis (Cav.) Trin. ex Steud.), which alternate with phytocenoses of narrow-leaved cattail (Typha angustifolia L.). These associations include great pond sedge (Carex riparia Curtis), creeping jenny (Lysimachia nummularia L.), threelobe beggarticks (Bidens tripartita L.), water mint (Mentha aquatica L.), great water-parsnip (Sium latifolium G. Arnaud ex Ciferri), fineleaf waterdropwort (Oenanthe aquatica (L.), Mackenzie's water hemlock (Cicuta virosa L.) and meadow weed species. Among hydrophytic higher plants, the most common ones are following: common hornwort (Ceratophyllum demersum L.), star duckweed (Lemna trisulca L.), claspingleaf pondweed (Potamogeton perfoliatus L.).

There are areas that are $80 \%$ overgrown with reed and cane vegetation, the average percentage of overgrowth of the riverbed in research points reaches $60 \%$. Species listed in the Red book of Ukraine and the Red list of the Dnipropetrovsk region have not been observed in the area of the planned operation.

Impact of planned Operation of the "Oktyabrska" mine on the vegetation of the riverbed of the Saksagan River. General mechanisms of the photosynthetic apparatus of the common hornwort (Ceratophyllum demersum L.) under the impact of the "Oktyabrska" mine. Macrophytes, as one of the main components of the aquatic ecosystem, are a labile and vulnerable part of the water self-purification system. Prevention of anthropogenic reduction of the self-cleaning potential of rivers is one of the conditions for sustainable use of biological resources of aquatic ecosystems and the biosphere as a whole ${ }^{12}$.

Under the exposure to ecotoxicants on plants, the most noticeable changes are observed in the structure of their cells, especially the photosynthetic apparatus. This is related to the fact that pollutants are mostly concentrated in cells (mainly in chloroplasts and vacuoles), thus the study on the flexibility of the photosynthetic apparatus and its ability to adapt to changing conditions of the phytocenosis environment is of great importance for studying the impact of toxicants on the physiological state of plants ${ }^{13}$.

The purpose of this part of the work is to determine the content and ratio of chlorophylls in the leaves of common hornwort (Ceratophyllum demersum L.) from different sections of the Saksagan River.

In the area influenced by the "Oktyabrska" mine, the amount of chlorophyll $a$ and $b$ in the leaves of common hornwort from all experimental sites was

\footnotetext{
12 Клепець О.В., Пилипенко М.О. Фітоіндикація екологічного стану малої паркової водойми. Біологія та екологія. 2018. № 4 (1). С. 73-85.

13 Макурина О.Н., Розина С.А., Розенцвет О.А. Динамика ферментативной активности и пигментного состава в тканях водного погруженного растения Ceratophyllum demersum в условиях воздействия ксенобиотиков и последующей реабилитации. Известия Самарского научного иентра Российской академии наук. 2015. Т. 17. № 4 (5). С. 1000-1007.
} 
approximately equal. However, a $20 \%$ decrease in the chlorophyll $b$ content has been observed at the return water (rain and meltwater) discharge point, along with a slight increase (5\%) in the chlorophyll $a$ content compared to variant from the site above the return water (rain and meltwater) discharge (Fig. 2). On the test site located $500 \mathrm{~m}$ below the discharge of return water (rain and meltwater), on the contrary, the content of chlorophyll $a$ was $5 \%$ lower, and chlorophyll $b$ was $28 \%$ higher than in samples from the site above the discharge of return water (rain and meltwater).

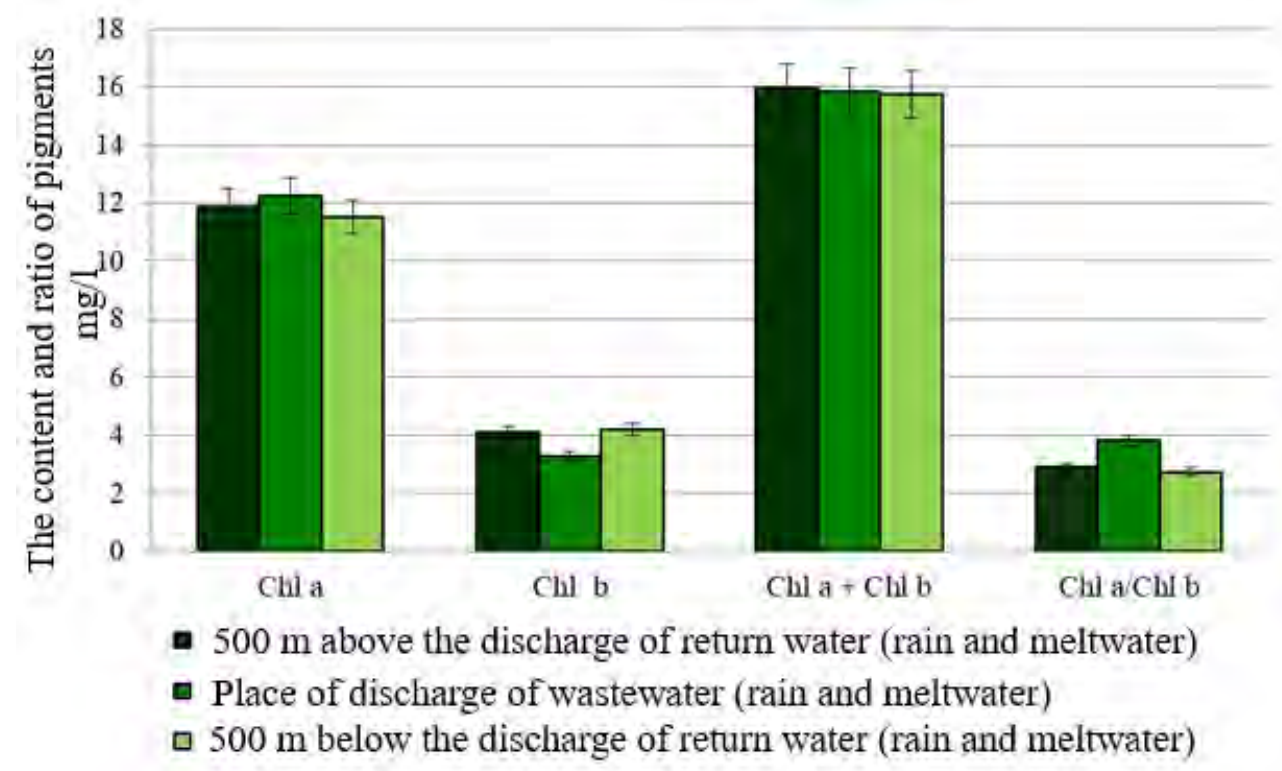

Figure 2. The content and ratio of pigments in the leaves of $\mathrm{C}$. demersum from various sited of the Saksagan River in the area influenced by the "Oktyabrska" mine: Chl a - chlorophyll a, Chl b-chlorophyll b, $\mathrm{Chl} \mathbf{a}+\mathrm{Chl} \mathbf{b}-$ the sum of chlorophyll a and chlorophyll $\mathbf{b}$, $\mathrm{Chl} \mathbf{a} / \mathrm{Chl} \mathbf{b}$ - the ratio of chlorophyll a to chlorophyll b

An increase in the amount of the chlorophyll $b$, which performs an supportive and protective role, as well as contributes to the maintenance of photosynthetic function ${ }^{14}$ indicates the adaptation of the common hornwort to increased anthropogenic load.

\section{CONCLUSIONS}

Upon the results of monitoring hydroecological studies conducted in the waters of the Saksagan River within the planned operation of the "Oktyabrska" mine, the following generalizations can be made:

\footnotetext{
${ }^{14}$ Павлов И.Н. Влияние выбросов алюминиевого завода на содержание хлорофилла в листьях деревьев и кустарников. Непрерывное экологическое образование и экологические проблемы : Сборник статей по матеріалам Всероссийской научно-практической конференции. Красноярск : СибГТУ, 2004. Т. 1. С. 164-170.
} 
1. In terms of hydrochemical composition, the water of the Saksagan River has a fairly high mineralization (1.75-2.84 g/l), which is caused by the complex influence of several factors: physical and geographical conditions, flow regulation (Makartivske, Kresivske, Saksaganske reservoirs).

2. The species composition of hydrobionts (phytoplankton, zooplankton, phytobenthos, microphytobenthos, macrophytes and ichthyofauna) naturally has a simplified structure, which is typical for reservoirs under anthropogenic load. There is a slight increase in the biodiversity of the ichthyofauna due to the spread of alien species (for example, the appearance of pumpkinseed, stone moroko, three-spined stickleback). Compared with last year's studies, there are no significant changes in the hydrobiocenoses of the experimental sites.

3. In the area influenced by the "Oktyabrska" mine, there are no protected territories (reserves, nurseries and natural monuments), objects of the Nature Reserve Fund, territories of the Emerland network (the Emerald network). Among the studied species of hydrobionts there are no endangered and listed in the Red book of Ukraine species of animals and plants.

4. Taking into account the existing conditions and the insignificant impact of the discharge of treated wastewater (rain, meltwater) into the Saksagan River (discharges № 1,2), the impact, in particular on the flora and fauna of the Saksagan River, is environmentally acceptable.

\section{SUMMARY}

The chapter presents the results of complex monitoring hydrobiological studies over the Saksagan River as part of the planned operation of the "Oktyabrska" mine. Hydrobiological samples were collected in June 2020 above wastewater outfall (residual rainfall and snowmelt runoff), at wastewater outfall (residual rainfall and snowmelt runoff) and below wastewater outfall (residual rainfall and snowmelt runoff). In water the basic hydrochemical indicators have been defined: hydrogen index $(\mathrm{pH})$, dissolved gases, biogenic elements, hardness, temperature, electrical conductivity, total mineralization (salinity). The quality of the aquatic environment was assessed by biotesting with daphnid Daphnia magna Straus and phytoindication by modified Mayers index. The analysis of the hydrochemical regime has been carried out according to generally accepted methods. Biotesting of water samples was carried out according to CTDC 211.1. 4.054-97. The biotesting with the use of Daphnia has shown that there is no acute toxicity of the aquatic environment. It has been found that the species composition of hydrobionts (phytoplankton, zooplankton, phytobenthos, microphytobenthos, and ichthyofauna) naturally has a simplified structure, which is typical for reservoirs under anthropogenic load. It has been noted that in terms of simplification of the ichthyofauna structure an observed increase in fish 
biodiversity is caused by the spread of invasive species, mainly pumpkinseed, stone moroko, and three-spined stickleback. The chapter presents general mechanisms of the photosynthetic apparatus of the common hornwort (Ceratophyllum demersum L.) under the impact of the "Oktyabrska" mine.

The study has revealed that the chlorophyll content and the ratio of chlorophyll forms $(\mathrm{Chl} \mathrm{a/Chl} \mathrm{b)} \mathrm{varied} \mathrm{in} \mathrm{C}$. demersum leaves depending on the influence of "Oktyabrska" mine. Taking into account the informative content of plastid pigments in the C. demersum leaves and the sensitivity of the species to anthropogenic pollution, its use as a bioindicator in the assessment of the ecological state of reservoirs in urban areas is promising.

\section{REFERENCES}

1. Методи гідроекологічних досліджень поверхневих вод / під ред. В.Д. Романенко. Київ, 2006. 628 с.

2. Методические рекомендации по сбору и обработке материалов при гидробиологических исследованиях. Зоопланктон и его продукция. Ленинград, ЗИН, 1984. 35 с.

3. Гринь В.Г. Об'ємно-вагова характеристика провідних видів фітопланктону Нижнього Дніпра. Питання екології $і$ ценології водних організмів Дніпра. АН УССР. Київ, 1963. С. 35-40.

4. Щербак В.I. Методи досліджень фітопланктону. Методичні основи гідробіологічних досліджень водних екосистем. Київ, 2002. С. 41-48.

5. Жадин В.И. Методика изучения донной фауны водоемов и экология донных беспозвоночных). Жизнь пресных вод СССР. Москва : Наука, 1956. T. 4. Ч. 1. С. 279-382.

6. Озінковська С.П., Єрко В.М., Коханова Г.Д., Тарасова О.М., Полторацька B.I. Методика збору i обробки іхтіологічних i гідробіологічних матеріалів 3 метою визначення лімітів промислового вилучення риб з великих водосховищ і лиманів України. Київ : IPГ УАAН, 1998. $47 \mathrm{c}$.

7. Исследования размножения и развития рыб : методическое пособие / под ред. Б.В. Кошелева, М.В. Гулидова. Москва : Наука, 1981. 224 с.

8. Кузнецов В.А. Количественный учет молоди рыб в водохранилищах и озерах (методические подходы и возможности). Tunoвые методики исследования продуктивности видов рыб в пределах их ареалов. Вильнюс, 1985. С. 26-35.

9. Коблицкая А.Ф. Определитель молоди пресноводных рыб. Москва : Легк. и пищ. пром-сть, 1981. 208 с.

10. Wintermans J.F.G.M., De Mots A. Spectrophotometric Characteristics of Chlorophyll $\mathrm{a}$ and $\mathrm{b}$ and Their Phaeophytins in Etanol. Biochimicaet Biophysica Acta. 1965. № 109 (2). P. 448-453. 
11. Current Protocols in Food Analytical Chemistry / E. Wrolstad (Editorin-Chief; Oregon State University), Terry E. Acree (Cornell University), Eric A. Decker (University of Massachusetts) and other. 2001. 1000 p.

12. Клепець О.В., Пилипенко М.О. Фітоіндикація екологічного стану малої паркової водойми. Біологія та екологія. 2018. № 4 (1). С. 73-85.

13. Макурина О.Н., Розина С.А., Розенцвет О.А. Динамика ферментативной активности и пигментного состава в тканях водного погруженного растения Ceratophyllum demersum в условиях воздействия ксенобиотиков и последующей реабилитации. Известия Самарского научного иентра Российской академии наук. 2015. Т. 17. № 4 (5). C. $1000-1007$.

14. Павлов И.Н. Влияние выбросов алюминиевого завода на содержание хлорофилла в листьях деревьев и кустарников. Непрерывное экологическое образование и экологические проблемь : Сборник статей по матеріалам Всероссийской научно-практической конференции. Красноярск : СибГТУ, 2004. Т. 1. С. 164-170.

Information about authors: Marenkov O. M., Candidate of Biological Sciences, Head of the Department of General Biology and Water Bioresources Oles Honchar Dnipro National University 72, Gagarin ave., Dnipro, 49050, Ukraine Aleksieieva A. A., Candidate of Biological Sciences, Research Laboratory of Hydrobiology, Ichthyology and Radiobiology Research Institute of Biology of Oles Honchar Dnipro National University 72, Gagarin ave., Dnipro, 49050, Ukraine 